\title{
Solutions for sustainable development of communities - the case of the mining basin of Oltenia, Romania
}

\author{
Bogdan Vladu ${ }^{l}$, Marin Nan ${ }^{1}$,Emilia Dunca ${ }^{1}$, Dorel Vitan ${ }^{l}$
}

'University of Petroșani, Romania; e-mail: bogdan.vladu@yahoo.com, nan.marins@gmail.com, emydunca@gmail.com, dorel.vitan@upet.ro

\section{Решения за устойчиво развитие на общностите - случаят с минния басейн на Олтения, Румъния}

Богдан Владу, Марин Нан, Емилия Дунка, Дорел Витан

Vladu, B., M. Nan, E. Dunca, D. Vitan. 2019. Solutions for sustainable development of communities - the case of the mining basin of Oltenia, Romania. Engineering Geology and Hydrogeology, 33, $77-84$.

\begin{abstract}
The mining basin of Oltenia comprises several development sub-areas of Gorj County. Development policies are the directions and principles of action that local public authorities draw in a number of key sectors. Determining sustainable development indicators for urban and rural areas will lead to the identification of development solutions for the Oltenia mining basin. The paper aims to identify the weaknesses by determining the human development indicators in the urban and rural areas affected by the restructuring of the mining industry.
\end{abstract}

Keywords: mining, sustainable development, restructuring, urban area, rural area.

Резюме. Миннодобивният басейн на Олтения обхваща няколко подзони за развитие на окръг Горж. Политиките за развитие са насоките и принципите на действие, които местните публични власти използват в редица ключови сектори. Определянето на показатели за устойчиво развитие на градските и селските райони ще доведе до идентифициране на решения за развитие на рудния басейн в Олтения. Статията има за цел да идентифицира слабостите чрез определяне на показателите за човешкото развитие в градските и селските райони, засегнати от преструктурирането на минната индустрия.

Ключови думи: минно дело, устойчиво развитие, преструктуриране, градска зона, селски район.

\section{Overview}

Gorj County is part of the South - West Development Region (Fig. 1). One of the priority functions of the development region of which Târgu Jiu Municipality is a part is the coordination of the regional development projects and the absorption of funds from the European Union. The South - West region covers $29,212 \mathrm{~km}^{2}$ or $12.25 \%$ of the total area of the country. 


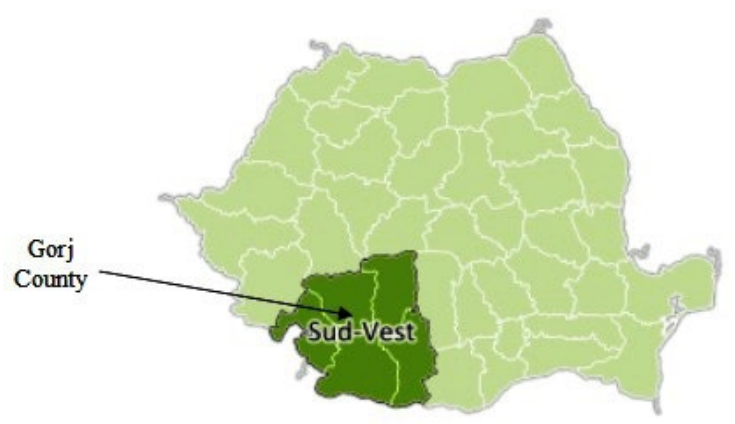

Fig. 1. The Gorj County, Romania

The South - West region has a relatively balanced distribution of relief forms, including mountains, plains, hills and plateaus. In the northern area of Oltenia, the relief is mountainous and hilly (Carpathians and sub-Carpathian area), with the predominant forests and alpine pastures. The plain area is mainly specialized in cereal cultivation. The hydrological network, made up mainly of the Danube River, the rivers Olt and Jiu, gives the region the main energy role in Romania $(71.57 \%$ of the total hydroelectric production).

Gorj county has several development sub-areas (Fig. 2), of which are also the communes Câlnic, Fărcăşești, Balti, Urdari, Plopşoru, Băneşti, Ioneşti and Ţânţăreni, together with the cities Rovinari and Turceni, being classified in the 5B development sub area (Vladu et al., 2018a,b).

Administrative-territorial commune Plopşoru has an area of 8002 ha, being considered the locality with the largest communal areas in Gorj County. It comprises 11 villages: Piscuri, Deleni, Olari, Plopșoru, Sărdănești, Izvoarele, Ceplea, Broșteni, Cursaru, Broșteni de Sus, Văleni, with about 6,703 inhabitants (Popescu, 1998; Irimie, 2003).

The main features of this development sub-area are:

- easily accessible major roads, roads and railways;

- the size of the communes and the importance of the two cities (Rovinari and Turceni);

- the relatively young population and the positive natural growth; heavily industrialized sub-area;

- average levels of development and tendencies to maintain/stabilize the population (Irimie, 2003).
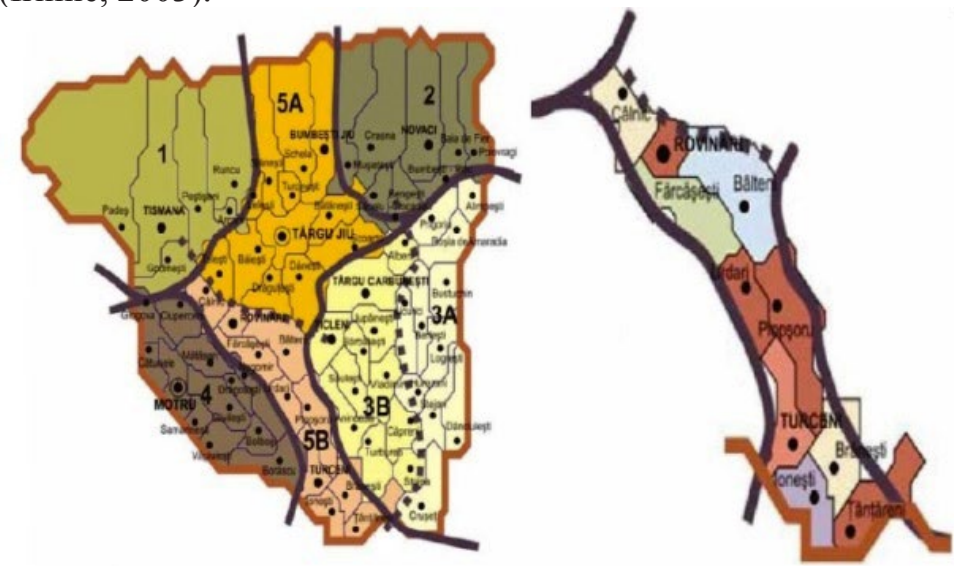

Fig. 2. The Sub zones of development in the Oltenia basin 
In addition to these positive characteristics there are also negative phenomena:

- serious environmental problems (landscape changes, pollution and atmospheric aggression);

- high degree of dependence on mining activities and electricity production;

Specific to this development sub-area 5B are social and environmental issues (Ciutacu et al., 1999).

The climate of Plopșorul commune is in the type of temperate-continental climate. The average annual temperature is within the range of $+10.2^{\circ} \mathrm{C}$, and the absolute minimum temperature is $-31.0^{\circ} \mathrm{C}$ and the maximum absolute temperature is $+40.6^{\circ} \mathrm{C}$.

\section{Population}

The population of Plopșoru commune consists of $49.99 \%$ women and $50.01 \%$ men, figure 3 (Popescu, 1998).

At present, there are a total of 6787 inhabitants, which have about 2200 households and a number of 2300 dwellings.

The labour force from Plopșoru commune indicates an active population occupied in the year 2012 of 1798 employees and an unemployed number of approx. 438.

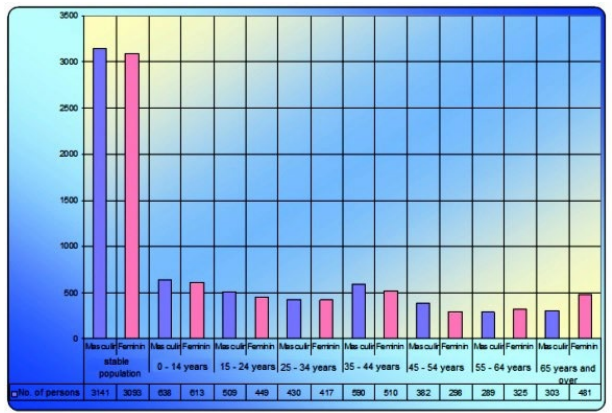

Fig. 3. Population distribution by age

\section{Occupation of land in the area}

Plopșoru commune occupies a total area of 8002 ha, of this area approx. 643 ha is located in the town and 7359 ha is in the town. According to the operating licenses, the perimeters of the Roşia de Jiu, Peșeana North and Peșeana South Quarries are also included here. In order to extract the lignite reserves from the economically exploitable mining fields, the working quarries will finally occupy the land areas presented in table 1. (Popescu, 2003; National Strategy for..., 2008).

Table 1. Areas occupied by mining, ha

\begin{tabular}{|l|c|c|c|}
\hline Quarry & Roşia de Jiu & Peşteana North & Peşteana South \\
\hline The area currently occupied & 1738,8 ha & 732,8 ha & 476,7 ha \\
\hline The area future occupied & 2187 ha & 859 ha & 553 ha \\
\hline Total & \multicolumn{3}{|c|}{3599 ha } \\
\hline
\end{tabular}

\section{Quality of environmental components}

As a result of the exploitation of the lignite deposit in the Roşia de Jiu, Peșteana North and Peșteana South quarries, the groundwater canvas was affected.

The main sources of air pollution with suspended particles in the Roşia de Jiu, North and South Pit quarries (Fig. 4.), Especially at the points of discharge and at the loading points on the haulage machines or on the conveyor belts front; transport and storage of dumped material in waste dumps, using waste disposal facilities, etc. 


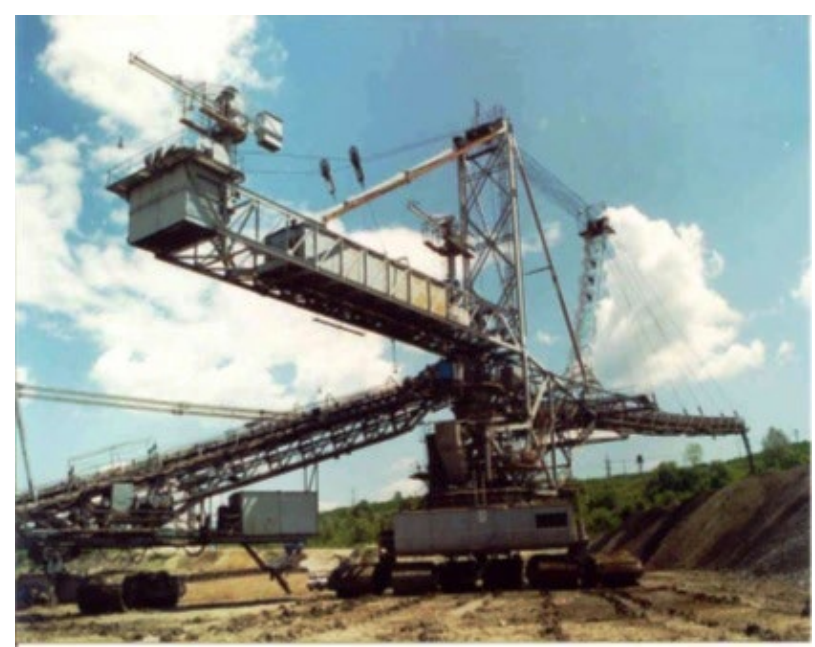

Fig. 4. Storage of sterile material in dumps.

The air currents draw dust from the quarry and from the transport roads, as well as the dust and even the tailings from the slopes and excavation steps polluted the atmosphere. They are transported at a great distance, on the lands and in the neighbouring localities, which is why the suspended powders have been determined.

From the periodic measurements made ,in situ” it was found that in certain work points the concentration in dust is higher than the allowed CMA (Fig. 5.)

As a result of the mining activity, about $51.47 \%$ of the surface of Plopșoru commune is affected by slip phenomena.

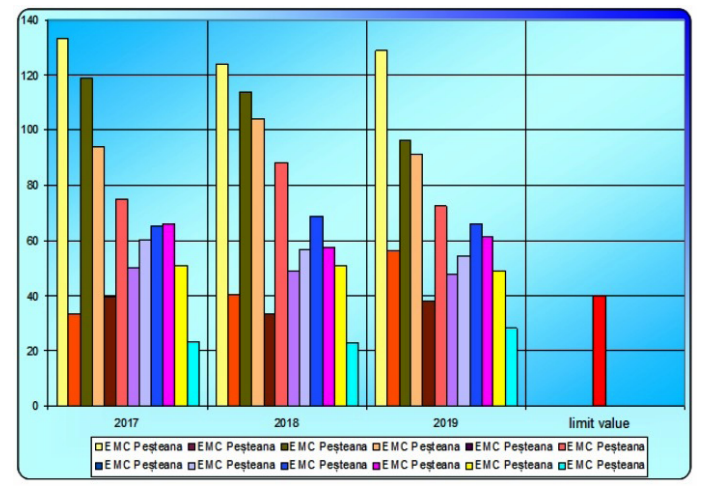

Fig. 5. Variation of PM 10 content in the area of the Peșteana mining perimeter

\section{The education system}

It is observed that the number of children of preschool age has decreased by $32.83 \%$, which will also lead to the reduction of general school students in the years to come from figures 6 and 7. About 75\% of the students who finish high school attend high school.

\section{The town hall of Plopșoru commune}

In accordance with the Strategy for economic-social and environmental development of Plopșoru, the mayoralty of Plopșoru commune proposes the following strategic objectives: 


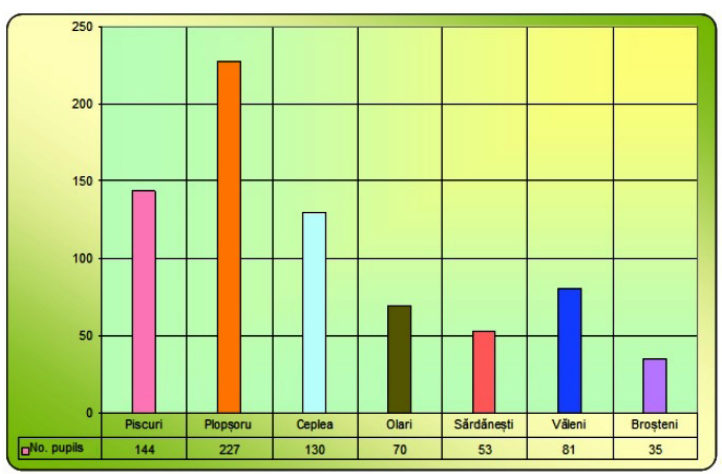

Fig. 6. The situation of students enrolled in primary school

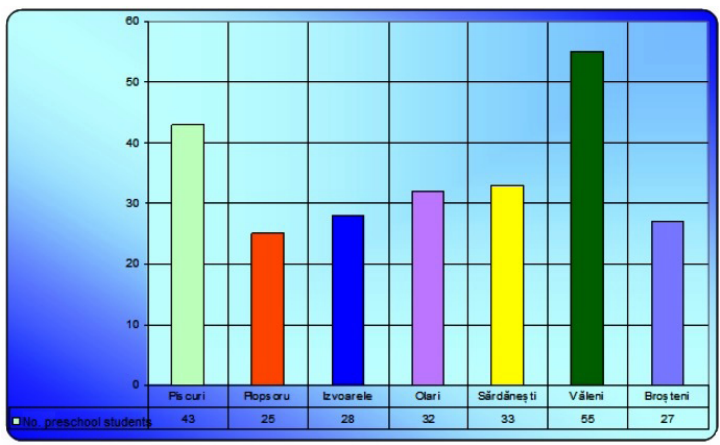

Fig. 7. Situation preschool students enrolled in kindergarten

- raising the standard of living of the inhabitants of Plopșoru commune;

- ensuring a high degree of competitiveness of all sectors of activity;

- supporting economic development by promoting the public-private partnership and creating attractive opportunities and facilities for potential domestic or foreign investors;

- promoting a performing agriculture and reviving the rural area, as a socioeconomic alternative of the urban environment;

- development and diversification of public services offered to citizens; moderni zation and development of physical infrastructure and other public utilities;

- protection of the environment, development and rehabilitation of the environmental infrastructure;

- business infrastructure development;

- capitalizing on the local tourism potential.

\section{Determining sustainable development indicators}

The degree of recovery $\left(G_{C}\right)$ of the income from a tax is determined as the ratio between the actual receipts obtained from a particular tax and the totality of the payment obligations of the citizens related to that tax, and is calculated with the relation (Vladu, et al., 2018a,b):

Where:

$$
\mathrm{G}_{\mathrm{C}}=\frac{\hat{\mathrm{I}}_{\mathrm{n}}}{\mathrm{D}_{\mathrm{b}}}
$$

$\hat{I}_{n}-$ realization proceeds, in lei,

$D_{b}$ - debit or payment obligations of taxpayers in lei. 
Thus, for 2017, the degree of recovery of income from property taxes is (Zamfir et al., 2007):

$$
G_{C}=\frac{\hat{I}_{n}}{D_{b}} \times 100=\frac{287,63}{1119,71} \times 100=25,69 \%
$$

For the collection of all local taxes $\left(G_{c a}\right)$, the degree of local tax collection is used, which is calculated as a weighted average of the collection rates for different taxes in relation to the tax collections, which is determined by the formula:

Where:

$$
\mathrm{G}_{\mathrm{ca}}=\frac{\Sigma\left(\mathrm{G}_{\mathrm{ej}} \cdot \mathrm{I}_{\mathrm{j}}\right)}{\Sigma \mathrm{I}_{\mathrm{j}}}
$$

$G_{e j}$ the degree of recovery of the various taxes,

$I_{j}$ - takings tax

For 2017 was calculated with the equation 7.2, the recovery of all taxes, it is:

$$
\mathrm{G}_{\mathrm{ca}}=\frac{\Sigma\left(\mathrm{G}_{\mathrm{ej}} \cdot \mathrm{I}_{\mathrm{j}}\right)}{\Sigma \mathrm{I}_{\mathrm{j}}}=\frac{(1903247 \cdot 25,69)+(8273301 \cdot 60,16)}{1903247+8273301}=53,71 \%
$$

For Plopșoru commune the level of taxation $\left(N_{f}\right)$ was determined (Vladu et al., 2018a,b). At a certain tax it is calculated as a ratio between the effective level of taxation and the maximum level of taxation allowed by law for that year, and is determined by the formula:

Where:

$$
\mathrm{N}_{\mathrm{f}}=\frac{\mathrm{N}_{\text {ef }}}{\mathrm{N}_{\text {max }}}
$$

$N_{e f}$ - level of taxation actually made,

$N_{\max }$ - maximum charge allowed by law for the current year.

In Plopşoru common in the 2017 tax changes for tax collection are calculated with the equation 3 :

$$
\mathrm{N}_{\mathrm{f}}=\frac{\mathrm{N}_{\mathrm{ef}}}{\mathrm{N}_{\max }} \times 100=\frac{1903247+8273301}{18282007,04} \times 100=55,66 \%
$$

In order to calculate the level of approved taxation $\left(N_{f a}\right)$ from all local taxes, it is determined as a weighted average for the level of taxation at local taxes according to the tax collections (Vladu et al., 2018a,b), namely:

Where:

$$
\mathrm{N}_{\mathrm{fa}}=\frac{\Sigma\left(\mathrm{N}_{\mathrm{fj}} \cdot \mathrm{I}_{\mathrm{j}}\right)}{\Sigma \mathrm{I}_{\mathrm{j}}}
$$

$N_{f a}$ - the level of taxation agreed;

$N_{f j}$ - the level of taxation for local taxes;

$I_{j}$ - takings tax.

In common Plopşoru to determine the agreed taxation for 2017 is used:

$$
\mathrm{N}_{\mathrm{fa}}=\frac{\Sigma\left(\mathrm{N}_{\mathrm{fj}} \cdot \mathrm{I}_{\mathrm{j}}\right)}{\Sigma \mathrm{I}_{\mathrm{j}}}=\frac{(1903247 \cdot 55,66)+(8273301 \cdot 55,66)}{1903247+827330 \mathrm{l}}=14,93 \%
$$

From the calculations made it can be seen that the level of taxation achieved in the village of Plopșoru does not fall within the level of taxation approved (Irimie, 2003; Popescu, 1998).

Currently, there are no prospects for making investments, as every five years the local council>s management structure and development ideas change. 
By determining the indicators of sustainable development, information is obtained regarding the periodic changes that take place locally in the village of Plopsoru. It also indicates the degree of achievement of the objectives set by the development strategies, of the indicators that can be determined and numerically.

By determining the human development index $\left(I_{D U}\right)$, other indicators can be calculated:

- life expectancy $\left(I_{S V}\right)$;

- educational level $\left(I_{N E}\right)$;

- standard of living (GDP / capita $-I_{P L}$ ).

The human development index, according to the specialized literature (Vladu et al., 2018a,b), has values between 0 and 1 , and calculates with the relation:

Where:

$$
\mathrm{I}_{\mathrm{SV}}=\frac{\mathrm{S}_{\mathrm{med}}-\mathrm{S}_{\min }}{\mathrm{S}_{\max }-\mathrm{S}_{\min }}=\frac{71,39-25}{72,25-25}=0,98
$$

$S_{\min }$ - is the minimum life expectancy, in years;

$S_{\text {med }}$ - is the average life expectancy, in years;

$S_{\max }-$ is the maximum life expectancy, in years.

$$
\mathrm{I}_{\mathrm{NE}}=\frac{2 \mathrm{I}_{\mathrm{GA}}-\mathrm{I}_{\mathrm{GCI}}}{3}=\frac{2 \cdot 0,593-0,62}{3}=0,18
$$

Where:

$I_{G A}$ - is the index of the degree of literacy,

$I_{G C I}-$ is the index of the degree of inclusion in education.

$$
\begin{gathered}
I_{\mathrm{GA}}=\frac{\mathrm{G}_{\mathrm{A}_{\operatorname{med}}}-\mathrm{G}_{\mathrm{A}_{\text {min }}}}{\mathrm{G}_{\mathrm{A}_{\text {max }}}-\mathrm{G}_{\mathrm{A}_{\text {min }}}}=\frac{75-55}{85-55}=0,66 \\
\mathrm{I}_{\mathrm{GCI}}=\frac{\mathrm{I}_{\mathrm{GCI}_{\text {med }}}-\mathrm{I}_{\mathrm{GCI}_{\text {min }}}}{\mathrm{I}_{\mathrm{GCI}_{\max }}-\mathrm{I}_{\mathrm{GCI}_{\min }}}=\frac{75-50}{90-50}=0,62
\end{gathered}
$$

Where:

$\mathrm{G}_{\mathrm{Amin}}-$ minimum literacy,

$\mathrm{G}_{\mathrm{Amed}}$ - average literacy,

$\mathrm{G}_{\mathrm{Amax}}$ - maximum literacy,

$\mathrm{I}_{\mathrm{GCImed}}-$ the average degree of inclusion in education,

$\mathrm{I}_{\mathrm{GCImin}}$ - the minimum degree of inclusion in education,

$\mathrm{I}_{\mathrm{GCImax}}$ - the maximum degree of inclusion in education.

$$
\begin{aligned}
& I_{\mathrm{PL}}=\frac{\lg \left(\frac{\mathrm{PIB}}{\operatorname{loc}}\right)-\lg \left(\frac{\mathrm{PIB}_{\text {min }}}{\operatorname{loc}}\right)}{\lg \left(\frac{\mathrm{PIB}_{\max }}{\operatorname{loc}}\right)-\lg \left(\frac{\mathrm{PIB}_{\min }}{\operatorname{loc}}\right)}=\frac{4,5448-4,5440}{4,5563-4,5440}=0,065 \\
& \mathrm{I}_{\mathrm{DU}}=\frac{\mathrm{I}_{\mathrm{SV}}+\mathrm{I}_{\mathrm{NE}}+\mathrm{I}_{\mathrm{PL}}}{3}=\frac{0,98+0,18+0,065}{3}=0,408
\end{aligned}
$$

From the calculations made the result for Plopssoru commune the value $I_{D U}=0.408$, this indicates to us, a human development is low the rural area.

In determining the Human Development Index for the rural area, the causes that led to its degradation were identified as:

- dependence of the inhabitants on the mining and energy industry; 
- destruction of agricultural areas by mining activity;

- lack of well-developed infrastructure;

- lack of investors in the area;

- a migration of the population to other areas or abroad.

\section{Conclusions}

The researches highlighted the possibilities of sustainable development of the rural area Plopssoru, influenced by the restructuring of the extractive industry.

The determination of the indicators of sustainable development could identify the weaknesses regarding the rural development, these are:

- dependence of the inhabitants on the mining and energy industry;

- serious environmental problems (landscape changes, pollution and atmospheric aggression);

- destruction of agricultural areas by mining activity;

- lack of well-developed infrastructure;

- lack of investors in the area;

- a migration of the population to other areas or abroad.

It is found that there are no prospects for investments in the rural area, because every five years the management structure of the local council and the ideas of development change.

\section{References}

Ciutacu, C., S. Pert, S. Steliana. 1999. Analysis of the Regional Social and Economic Background. Case studies for RICOP, with the financial support of the European Training Foundation. Turin, $97 \mathrm{p}$.

National Strategy for Sustainable Development of Romania. 2008. Official Gazette No. 824/8 December 2008, Government of Romania, Ministry of Environment and Sustainable Development, Horizons 2013 - 2020 - 2030, Bucharest, 110-112 (in Romanian).

Irimie, I., 2003. Possibilities of operationalizing the concept of sustainable development for a mining region, using the notion of community capital and evaluation indicators. The Mine Revue, no. 9-10, 71-91 (in Romanian).

Popescu, C. 1998. Regional reactions of the industry in the context of the restructuring process. Geographic Magazine, 14-19 (in Romanian).

Popescu, I. 2003. Local economic development. Public Administration and Management, Vol. II, ASE Publishing House, Bucharest, 235-241 (in Romanian).

Vladu, B., M. Nan, E. Dunca, C. Plotogea. 2018a. Theoretical and experimental research on the quantification of the fundamental elements in the assessment of sustainable development strategies in the Oltenia basin. International Multidisciplinary Scientific Geo Conference Surveying Geology and Mining Ecology Management, SGEM, 18(5.2), Albena, Bulgaria, 1003-1010 (in Romanian).

Vladu, B., M. Nan, E. Dunca, C. Plotogea. 2018b. Contributions to the sustainable development of the areas affected by the exploitation in the Oltenia basin. Case Study. Research report 3. University of Petroșani, Faculty of Mechanical and Electrical Engineering, 48-52 (in Romanian).

Zamfir, C, L. Stoica, M. Stănculescu (eds.), 2007. Designing social development. Methodological guide. ICCV, University of Bucharest, Romanian Social Institute, Bucharest, $91 \mathrm{p}$. 